\title{
IDEOLOGI PENDIDIKAN PESANTREN KONTEMPORER: Pendekatan Strukturalisme
}

\author{
Al Husaini M. Daud \\ Jurusan Tarbiyah STAIN Malikussaleh Lhokseumawe \\ Jl. Cempaka No. 1 Lancang Garam, Lhokseumawe, 24300 \\ e-mail: beck_roprophai@yahoo.com
}

\begin{abstract}
Abstrak: Islam adalah dasar bagi ideologi pesantren. Penanaman nilai-nilai Islam bagi santri merupakan hal penting yang akan menjadi modal bagi santri setelah berhadapan dengan realitas masyarakat. Tulisan ini mendiskusikan ideologi pesantren dengan menggunakan pendekatan Strukturalisme dengan tujuan untuk membahas strategi pelaksanaan ideologi pendidikan kepada santri sehingga nilai-nilai filosofi diterapkan dalam kehidupan sehari-hari. Penulis menemukan bahwa strategi penyebaran ideologi pendidikan Islam pesantren adalah melalui kepiawaian seorang kiai dan kemapanan ilmu yang dimilikinya sebagai figur dalam masyarakat. Jaringan yang dibangun antara alumni dan masyarakat membuat nilai-nilai ideologi menjadi lebih mudah dilaksanakan. Di samping peran kiai sebagai pemimpin sangat dominan membuat proses transformasi ideologi melekat dalam seluruh aktivitas kehidupan para santri.
\end{abstract}

\begin{abstract}
The Ideology of Contemporary Pesantren Education: A Structuralism Approach. Islam is the ideological foundation of Pesantren. The cultivation of Islamic values in students is an important aspect that should become a force in facing the social reality. This article discusses the ideology of traditional Islamic boarding School or Pesantren. In doing so, this work will be approached by structuralism. The objective of this article is to discuss the strategy of education ideology implementation to all santri so that such values of the Pesantren ideology can be deeply rooted in their daily life. The author finds that dissemination strategy of Islamic education ideology is via the kiai's expertise and his sound knowledge as a central figure for his community. In addition, the network that constructed between alumnus and society make that ideology values become easier to implement. What's more, the dominant role enjoyed by the Kiai lead to transformation process very attached to the whole social activities of the santris.
\end{abstract}

Kata Kunci: ideologi pendidikan, pesantren, Strukturalisme 


\section{Pendahuluan}

Fenomena munculnya ide "pesantren terpadu" dalam dunia pendidikan pesantren, sebagaimana juga pendidikan formal menghadirkan sosok "sekolah unggul" sebagai andalan penyelesaian problematika out put (produk) institusi pendidikan dewasa ini, pada awalnya merupakan dampak dari pertikaian ideologi dan perspektif pendidikan. Pertikaian tersebut tanpa disadari telah menyeret eksistensi institusi itu mengalami transisi dari model pendidikan yang sama sekali tidak menghiraukan perubahan masyarakat menuju model pendidikan pembangunan; di mana pendidikan berorientasi pada penguatan pembangunan tanpa dipersoalkan apa hakikat ideologi yang menjadi dasar bagi pembangunan itu sendiri. ${ }^{1}$

Pesantren sebagai sub-kultur masyarakat saat ini sedang diuji untuk mampu memberikan solusi jernih terhadap hentakan perkembangan dunia pendidikan masa kini yang cenderung mengarah kepada proses dehumanisasi akibat Kapitalisme, dan nyaris tidak lagi berpijak pada hakikat pendidikan itu sendiri yakni untuk memanusiakan manusia. Institusi pendidikan Islam paling awal di Indonesia, yang secara kultural diwakili oleh Pesantren dituntut untuk bisa memberikan jawaban terhadap persoalan yang pelik dan menyulitkan, yakni antara memelihara sistem dan struktur sosial yang ada atau harus berperan kritis dalam melakukan perubahan sosial dan tranformasi menuju dunia yang lebih adil, yakni mensejajarkan sekaligus mensinergikan eksistensi dan esensinya dengan perkembangan zaman. Dilema peran tersebut akan terjawab melalui pemilihan paradigma dan ideologi pendidikan yang mendasarinya.

Ajaran Islam merupakan asas ideologi pendidikan pesantren sebagai satu-satunya institusi pendidikan islam yang tertua di Indonesia, di mana kaitan erat antara aktivitas belajar dan motivasi utamanya cukup kentara. Catatan sejarah melukiskan bahwa motivasi umat Islam dalam menuntut ilmu adalah adanya "status istimewa" dari Allah SWT. Status tersebut bukan saja dapat menempatkan seseorang pada posisi terhormat di dunia ini, namun juga mendapatkan derajat tinggi di sisi-Nya di akhirat nanti. Kelebihan seseorang yang tekun dalam menuntut ilmu (al-'alîm) dibandingkan dengan mereka yang beribadah (al-'abid) sepanjang waktu, bagaikan kelebihan Nabi Muhammad SAW. atas seorang Muslim yang paling lemah. Abdurrahman Mas'ud melukiskan bahwa bukti signifikan wahyu pertama tentang intruksi Ilahi "Iqra" menunjukkan arti penting membaca sebagai suatu aktivitas intelektual dan menulis yang disimbolkan dengan "al-Qalam". ${ }^{2}$ Ajaran Iqra' merupakan suatu seruan pencerahan intelektual yang telah terbukti secara empiris dalam banyak literatur sejarah mampu mengubah peradaban manusia dari era kerisauan moral-intelektual ke masa keceriaan peradaban tinggi di bawah payung petunjuk Ilahi.

${ }^{1}$ Mansour Fakih, "Pengantar," dalam William O’neil, Ideologi-ideologi Pendidikan, cet. 2, (Yogyakarta: Pustaka Pelajar, 2008), h. xi.

${ }^{2}$ Abdurrahman Mas'ud, Intelektual Pesantren: Perhelatan Agama dan Tradisi (Yogyakarta: LKiS, 2004), h. 31. 
Seruan Iqra' menjadi firman pertama yang mengidentifikasikan peran dan fungsi "membaca" dan "menulis" sebagai pilar yang sangat signifikan dalam kehidupan sejarah peradaban umat manusia. Bagi seorang Muslim, istilah al-ta'allum thula al-hayaâh (belajar sepanjang hayat) mengandung makna dan nilai yang sangat sakral dan tinggi. Menuntut ilmu tidak sekedar memenuhi kebutuhan hidup (bertahan hidup), tetapi lebih merupakan tugas dan kewajiban yang diemban dari Tuhan. Mas'ud mengutip sabda Nabi yang dilansir dalam kitab Ihya' 'Ulûm al-Dîn karya al-Gazâlî bahwa tinta para pelajar setara dengan darah para syuhadâ'. Karenanya, guru dan murid sebagai aktor utama dalam proses pembelajaran merupakan "orang-orang terpilih" dalam masyarakat untuk mengembangkan dan mengamalkan ilmu pengetahuan. ${ }^{3}$ Motivasi tersebut menjadikan al-Qur'an dan hadis sebagai satu-satunya kurikulum inti yang dipelajari oleh umat Islam dari masa ke masa. Dari dua pilar sumber ilmu itu, umat Islam telah mewarisi semangat mencari ilmu dari generasi ke generasi.

Motivasi religius yang sudah mengakar erat dalam jiwa setiap generasi Muslim menjadi sebuah ideologi yang cukup kuat dan menyatu dalam setiap fase sejarah kehidupan umat Islam. Penguatan ideologi-ideologi tersebut kepada generasi Muslim selanjutnya ditransformasikan secara sistematis lewat lembaga pendidikan. Lembaga pendidikan Islam yang secara berkesimbungan dan setia menjaga dan memelihara nilainilai ideologi pendidikan Islam adalah lembaga pendidikan pesantren. Kontsruksi integralitas nilai pendidikan di lembaga ini merupakan pengejawantahan dari hasil permentasi budaya yang melingkungi masyarakat yang kental dengan nilai-nilai Islam. Unsur nilai-nilai ajaran Islam di lembaga pendidikan tradisional ini tergambar jelas dalam praktik pergaulan keseharian santrinya, terutama nilai moral (akhlak) yang melandasi kesuksesan lembaga ini dalam membentuk jati diri anak bangsa menjadi cerdas tidak saja dari aspek intelektual, tetapi juga dari aspek spiritual dan sosial kemasyarakatan. Komentar Karel A. Steenbrink sekitar bagaimana proses internalisasi nilai-nilai ideologi di lembaga pendidikan Islam klasik ini terjadi;

'Untuk meresapi jiwa keislaman, pesantren tidak hanya dihormati sebagai tempat belajar, tetapi lebih ditekankan sebagai tempat tinggal yang seluruhnya dipenuhi dan diresapi dengan nilai-nilai agama. Tidak ada tempat lain di mana salat didirikan dengan taat seperti di sana. Pada siang hari, di mana-mana orang dapat mendengar para santri membaca al-Qur'an dengan lagu yang indah, memperbaiki bacaan dengan tajwid yang benar, atau hanya untuk mengharapkan pahala dari membaca al-Qur'an. Pada malam hari juga dapat dijumpai suasana orang membaca al-Qur'an, melagukan kalam Ilahi dan mendirikan salat di tengah keheningan malam.'4

Bangunan nilai yang melekat pada tubuh lembaga pendidikan tradisional ini

${ }^{3}$ Ibid., h. 32.

${ }^{4}$ Karel A. Steenbrink, Pesantren, Madrasah dan Sekolah (Jakarta: LP3ES, 1986), h. 16. 
didasari pada tujuan pendiriannya. Binti Maunah mengidentifikasi bahwa setidaknya ada dua alasan mengapa lembaga pendidikan Islam ini ada. Pertama, pesantren dilahirkan untuk memberikan respons terhadap situasi dan kondisi sosial suatu masyarakat yang tengah dihadapkan pada runtuhnya sendi-sendi moral, melalui transformasi nilai yang ditawarkan (amar ma'rûfnahy munkar). Kedua, untuk menyebarluaskan misi universalitas ajaran Islam ke seluruh penjuru nusantara yang berwatak pluralis, baik dalam dimensi kepercayaan, budaya maupun kondisi sosial masyarakat. ${ }^{5}$

Elemen utama bangunan sistem pendidikan Islam tradisional ini meliputi kiai, santri, masjid, asrama dan pengajian kitab kuning. ${ }^{6}$ Keterpaduan antar elemen tersebut juga memberi keunikan tersendiri bagi suatu sistem dan model pendidikan yang khas, sekaligus membedakan dengan pendidikan lainnya. Secara antropologis, lembaga pendidikan pesantren lahir dari proses kebiasaan-kebiasaan yang sering terjadi di lingkungan sosial kemasyarakat, kebiasan-kebiasan yang baik menurut ajaran agama Islam dipraktikkan oleh individu dan kelompok masyarakat serta akhirnya menjadi norma yang ditaati dan dipatuhi oleh anggota masyarakat. Lembaga pendidikan pesantren dalam masyarakat merupakan sebuah cita-cita, sikap dan perlengkapan kebudayaan, bersifat kekal serta bertujuan untuk memenuhi kebutuhan masyarakat agar lebih teratur dan tertib. Keberadaan lembaga pendidikan ini dalam masyarakat merupakan suatu komunitas untuk menjaga kestabilan suatu sistem masyarakat yang sedang didiaminya

Kiai merupakan figur sentral dalam suatu pesantren dan komunitas masyarakat setempat. Hal ini dikarenakan, selain dia memiliki pemahaman agama yang komprehensif sehingga tidak saja menjadi rujukan keilmuan bagi muridnya di lingkungan lembaga ini, tetapi sekaligus juga menjadi pemimpin gerakan sosial kemasyarakatan. Kedalaman ilmu pengetahuan keislaman dan kesalehan sosial seorang kiai menjadikan pesantren sebagai pusat pendidikan agama Islam yang memiliki basis sosial yang jelas dan kuat, karena keberadaannya menyatu dengan masyarakat. Ketika lembaga-lembaga sosial lain belum berjalan secara fungsional, maka pesantren -begitu juga Dayah di Aceh, Surau di Sumatera Barat- menjadi pusat aktifitas sosial masyarakat; mulai orang belajar agama, bela diri, mengobati orang sakit, dan mencari jodoh sampai pada menyusun perlawanan terhadap kaum penjajah, semua dilakukan di pesantren yang dipimpin oleh seorang kiai. ${ }^{7}$

Pesantren sebagai sebuah subkultur, dari awal kemunculannya telah menjadikan nilai-nilai tersebut sebagai bagian yang terpenting dalam praktik pendidikan Islam di Indonesia. Karena itu, Amin Haedari mengungkapkan bahwa dengan modal elemen

${ }^{5}$ Binti Maunah, Tradisi Intelektual Santri dalam Tantangan dan Hambatan Pendidikan Pesantren di Masa Depan (Yogyakarta: Teras, 2009), h. 25-26.

${ }^{6}$ M. Isa Sulaiman, Sejarah Aceh: Sebuah Gugatan Terhadap Tradisi (Jakarta: Pustaka Sinar Harapan, 1997), h. 32.

${ }^{7}$ Ngatawi el-Zastrow, "Dialog Pesantren-Barat: Sebuah Transformasi Dunia Pesantren," dalam Mihrab, edisi I, tahun IV, 2006. h. 4. 
nilai tersebut, sebuah pesantren memiliki hubungan yang sangat erat dengan kehidupan masyarakat dan menjadi salah satu penopang pilar pendidikan di bumi Nusantara. ${ }^{8}$ Berikut pernyataan Abdurrrahman Wahid dalam satu tulisannya:

Ada tiga elemen dasar yang mampu membentuk pondok pesantren sebagai sebuah subkultur. Pertama, pola kepemimpinan pondok pesantren yang mandiri tidak terkooptasi oleh negara. Kedua, kitab-kitab rujukan umum yang selalu digunakan dari berbagai abad. Ketiga, sistem nilai (value system) yang digunakan adalah bagian dari masyarakat luas. ${ }^{9}$

Lebih lanjut, Haedari mengutip pernyataan Abdurrahman Wahid bahwa pada fasefase awal, sistem dan kurikulum pembelajaran yang dilakukan pada lembaga pendidikan pesantren tidak mengkhususkan pada materi ilmu-ilmu keislaman dan pengkaderan ulama saja, tetapi juga pada waktu itu pesantren membuat pendidikan umum yang di dalamnya tidak hanya mengajarkan materi agama. Posisi lembaga pesantren ketika itu sebagai lembaga pendidikan alternatif bagi rakyat yang tidak mendapatkan pendidikan di lembaga pendidikan bentukan kaum Kolonial yang hanya diperuntukkan bagi kalangan darah biru. ${ }^{10}$

Karena pesantren merupakan satu tempat yang dipersiapkan untuk memberikan pendidikan agama, sejak dari tingkat rendah sampai ke tingkat belajar lebih lanjut, ${ }^{11}$ maka unsur nilai-nilai ajaran Islam di lembaga pendidikan tradisional Islam ini sangat nyata kelihatan dalam praktik pergaulan keseharian para santri, terutama nilai-nilai moral (akhlak) yang melandasi kesuksesan lembaga ini dalam membentuk jati diri anak bangsa menjadi cerdas tidak saja dari aspek intelektual, tetapi juga dari aspek spiritual dan sosial kemasyarakatan. Karena itu, pesantren itu merupakan satu tempat yang dipersiapkan untuk memberikan pendidikan agama, sejak dari tingkat rendah sampai ke tingkat belajar lebih lanjut.

Komunitas pesantren merupakan bagian yang tidak terpisahkan dari ideologi Sunni atau Ahlussunnah waljamâ'ah bila ditinjau dari aspek tauhid (teologi), ideologi Syafi'isme dari aspek pemikiran (fikih) dan ideologi Ghazalisme dari segi etika (tasawuf). Sunnisme dalam hal ini ditunjukkan dengan kecenderungan orang untuk lebih menjadikan al-Qur'an dan sunnah Nabi sebagai sumber utama dalam mencari penyelesaian debat ideologis dan sebagai pegangan hidup, daripada sekedar penggunaan akal untuk mematahkan otoritas hadis seperti kaum Mu'tazilah. Distingsi yang sangat kontras antara Sunni dan Mu'tazilah adalah pada referensi sumber ajaran. Kaum Mu'tazilah cenderung dipengaruhi

${ }^{8}$ Amin Haedari, Panorama Pesantren dalam Cakrawala Modern (Jakarta: Diva Pustaka Jakarta, 2005), h. 1.

${ }^{9}$ M. Dawam Raharjo (ed.), Pesantren dan Pembaharuan, cet. 6 (Jakarta: LP3ES, 1988), h. 35.

${ }^{10}$ Ibid., h. 11-12.

${ }^{11}$ Abdurrahman Saleh Abdullah, Teori-teori Pendidikan Berdasarkan al-Qur'an, terj. M. Arifin (Jakarta: Rineka Cipta, 1990), h. 11. 
ole ide-ide para filosof, sedangkan kaum Sunni sepenuhnya dipengaruhi oleh salafal-shalîh dan ulama terpercaya Abad Pertengahan.

Ideologi pendidikan pesantren yang lahir dari akar ajaran Islam itu sebagaimana dicatat dalam lembaran sejarah peradaban Islam di Indonesia terbukti mampu mempengaruhi banyak kalangan masyarakat menjadi satu pilihan kedirian (keyakinan/prakiraan pribadi) dalam aktivitas keilmuan. Praktik-praktik pendidikan telah berlangsung di mana-mana. Al-Qur'an dan hadis menjadi "kurikulum" yang paling utama dan terbukti mampu memberi inspirasi kepada alumni-alumninya untuk bersikap bijak dalam menjawab tantangan global. Bahkan pasca kemerderkaan Indonesia pesantren harus berhadapan dengan gencarnya arus modernsasi yang berakibat pada terjadinya perubahan format, bentuk, dan metode pendidikan. Namun demikian, perubahan tersebut tidak sampai merubah visi, misi, dan orientasi pesantren. Perubahan tersebut hanya pada sisi luarnya saja, sementara pada sisi dalam, yakni ruh, semangat, pemahaman substansi keagamaan, nilai-nilai, tradisi, dan ideologi pesantren masih tetap dipertahankan. ${ }^{12}$

Kemajuan ilmu pengetahuan, terutama dalam bidang pengetahuan keagamaan, merupakan tanggapan terhadap tuntutan religius dan kultural yang relevan dengan kondisi geografis dan geobudaya bangsa Indonesia. Persoalan kemudian adalah bagaimana strategi penerapan ideologi tersebut kepada para santri sehingga nilai-nilai filosofi dari ideologi pendidikan pesantren itu mengakar kuat dalam praktik kehidupan keseharian mereka.

\section{Ideologi dan Pendekatan Strukturalisme}

Ideologi pada dasarnya mengusung dua fungsi utama. Pertama sebagai fungsi sosial, yang mengikat masyarakat secara bersama-sama. Kedua sebagai fungsi individu, yang mengatur peran kepribadian individu yang matang. Kedua fungsi ini bersatu untuk melegitimasi kekuasaan. Dalam perkembangan masyarakat terkini, kekuasaan menjadi alat legitimasi sebuah dasar ideologi yang memberikan klaim terhadap rencana yang besar dan masuk akal, dan juga menetapkan moral sebagai dasar manipulasi sosial untuk alasan perkembangan. Singkatnya, ideologi hanya mendukung para elite dan untuk membenarkan penggunaan kekuatan. Karenanya, ada dua aspek yang harus diperhatikan dalam ilmu sosial modern untuk menjembatani kegelisahan ideologi, yakni aspek solidaritas dan aspek identitas. ${ }^{13}$

Namun, sebelum beranjak lebih jauh, definisi ideologi bagaimana pun juga sangatlah penting, ideologi itu lebih dari sekedar doktrin. Ia berhubungan erat dengan kegiatan individu dan praktik keduniaan dengan setting makna yang lebih luas dan praktiknya cenderung lebih terhormat dan lebih dihargai sebagai corak perilaku masyarakat. Ideologi

${ }^{12}$ Zastrow, "Dialog Pesantren-Barat," h. 5.

${ }^{13} \mathrm{Al}$ Husaini M. Daud, "Ideologi dan Ketidakpuasan," (Makalah, tidak diterbitkan), h. 2. 
merupakan istilah umum yang dipakai untuk gagasan-gagasan umum berpotensi dalam situasi tingkah laku tertentu. Ideologi tidak sama dengan filsafat. Posisi abstraksi yang mengherankan bahwa ia lebih ringkas dari pada abstraksi-abstraksi yang meliputi di dalamnya. Kekuatan ideologi dan ideologi kreatif (seperti gagasan-gagasan agama, anggota pendeta yang inovatif) memperluas peran individu. ${ }^{14}$

Kemunculan term ideologi itu sendiri sebenarnya di satu pihak berawal akibat dari kehancuran tatanan sosial. politik, dan intelektual yang menyertai Revolusi Industri, yaitu tersebarnya gagasan demokrasi, politik gerakan massa, dan sebuah gagasan yang menganggap bahwa karena kita telah menciptakan dunia, maka kita juga dapat menciptakannya kembali. di lain pihak, ideologi merupakan hasil dari semakin meningkatnya pluralitas masyarakat dan berhubungan dengan kelompok-kelompok yang bersaing, di mana kepentingan bagian-bagiannya dilayani oleh ideologi tersebut. ${ }^{15}$ Fungsi positif dari sebuah ideologi menurut Vigo sebagaimana dikutip oleh Achmadi, mencakup 3 (tiga) hal fungsi utama, yaitu (1) memberikan legitimasi dan rasionalisasi terhadap perilaku dan hubungan-hubungan sosial dalam masyarakat; (2) sebagai dasar atau acuan pokok bagi solidaritas sosial dalam kehidupan kelompok atau masyarakat, dan (3) memberikan motivasi bagi para individu mengenai pola-pola tindakan yang pasti dan harus dilakukan. ${ }^{16}$

Sementara menurut kaum Positivistik, ideologi adalah segala penilaian etis, norma, teori-teori metafisik dan keagamaan. Semua yang termasuk ideologi itu merupakan keyakinan yang tidak ilmiah karena tidak rasional dan hanya merupakan keyakinan subjektif. Kuntowijiyo seperti dikutip oleh Achmadi menyatakan bila ideologi dikaitkan dengan ilmu pengetahuan maka ideologi bersifat subjektif, normatif, dan eksklusif (tertutup), sedangkan ilmu pengetahuan memiliki watak objektif, faktual, dan inklusif (terbuka). ${ }^{17}$

Beberapa pendapat tentang bagaimana sebuah ideologi menyebar dan bekerja dalam memengaruhi tingkah laku manusia di antaranya sebagaimana dikemukakan oleh Terry Eagleton yang dikutip oleh Bagus Takwin adalah strategi penyebaran sebuah ideologi terdiri dari rasionalisasi, universalisasi dan naturalisasi. Rasionalisasi adalah usaha untuk memberikan argumentasi-argumentasi yang seakan-akan tampak rasional. Universalisasi adalah usaha menampilkan gagasan-gagasan yang diklaim berlaku universal dan diperlukan di mana-mana. Sedangkan naturalisasi merupakan usaha untuk menampilkan sebuah ideologi/kepercayaan sebagai suatu yang tampak alamiah. ${ }^{18}$

${ }^{14}$ Ibid.

${ }^{15}$ David Mc Lelland, Ideologi Tanpa Akhir, terj. Muhammad Syukri (Yogyakarta: Kreasi Wacana, 2005), h. 4-5.

${ }^{16}$ Achmadi, Ideologi Pendidikan Islam: Paradigma Humanisme Teosentris (Yogyakarta: Pustaka Pelajar, 2005), h. 19-20.

${ }^{17}$ Ibid., h. 20.

${ }^{18}$ Bagus Takwin, Akar-akar Ideologi: Pengantar Kajian Konsep Ideologi dari Plato hingga Bourdieu, cet. 2 (Yogyakarta: Jalasutra, 2009), h. 127. 
Namun sebelumnya, aliran paradigma dalam ideologi pendidikan menurut Henry Giroux dan Aronowitz sebagaimana dikutip William F. O'neil dibagi ke dalam tiga aliran. Pertama, paradigma konservatif. Paradigma ini mengilustrasikan bahwa ketidakkesederajatan masyarakat merupakan suatu hukuman keharusan alami dan merupakan ketentuan sejarah. Paradigma ini dibangun berdasarkan keyakinan bahwa masyarakat pada dasarnya tidak bisa merencanakan perubahan atau memengaruhi perubahan sosial. Dengan kata lain, paradigma ini tidak menganggap masyarakat memiliki kekuatan atau kekuasaan untuk merubah kondisi mereka. Kedua, Paradigma liberal yang beranggapan bahwa pendidikan tidak ada kaitannya dengan persoalan politik dan ekonomi masyarakat. Namun demikian, kaum liberal berusaha menyesuaikan pendidikan dengan persoalan ekonomi dan politik di luar dunia pendidikan dengan jalan memecahkan berbagai masalah yang ada dalam pendidikan dengan usaha reformasi "kosmetik". Umumnya yang dilakukan adalah seperti perlunya membangun kelas dan fasilitas baru, memodernisasi peralatan sekolah dengan pengadaan komputer yang lebih canggih dan laboratorium, serta berbagai usaha untuk menyehatkan rasio murid-guru. Ketiga, adalah paradigma kritis. Pendidikan bagi mereka merupakan arena perjuangan politik. Jika bagi kaum konservatif pendidikan bertujuan untuk menjaga status quo, sementara bagi kaum liberal untuk perubahan moderat, maka paradigma kritis menghendaki perubahan struktur secara fundamental dalam politik ekonomi masyarakat di mana pendidikan berada. ${ }^{19}$

Dalam perspektif kritis, urusan pendidikan adalah melakukan refleksi kritis terhadap the dominant ideology ke arah transformasi sosial. Terkait dengan ini, ideologi yang semula merupakan produk pemikiran manusia yang khas akibat dari semakin meningkatnya pluralitas masyarakat yang melahirkan kekuatan bagi meningkatnya proses demokratisasi politik yang memunculkan revolusi komunikasi sehingga tingkat melek huruf semakin meluas dengan tensi yang cukup signifikan. ${ }^{20}$

Peta ideologi pendidikan Giroux sebagaimana diungkapkan di atas sejalan dengan analisis Freire yang menggolongkan kesadaran manusia menjadi kesadaran magis, kesadaran naif dan kesadaran kritis. Kesadaran magis adalah tingkat kesadaran yang tidak mampu mengetahui kaitan antara satu faktor dengan faktor lainnya. Sementara kesadaran naïf adalah lebih melihat "aspek manusia" menjadi akar penyebab masalah masyarakat. Dalam hal ini, masalah etika, kreatifitas, dan need for achievement dianggap sebagai penentu perubahan sosial. Sedangkan kesadaran kritis, yakni kesadaran yang lebih melihat aspek sistem dan struktur sebagai sumber masalah.

Secara umum, strategi ideologi berfungsi mempertahankan kekuasaan. Pihak yang berkuasa cenderung berusaha mempertahankan dominasinya terhadap pihak yang

${ }^{19}$ William F. O'neil, Ideologi-ideologi Pendidikan, terj. Omi Intan Naomi, cet. 2 (Yogyakarta: Pustaka Pelajar, 2008), h. xiii-xvi.

${ }^{20}$ Lelland, Ideologi Tanpa Akhir, h. 5. 
dikuasai. Berbagai kajian ideologi menunjukkan adanya persinggungan antara makna dan dominasi dalam persoalan ideologi. Berbagai makna yang terkandung dalam ideologi tersebar sedemikian rupa dan diinternalisasikan kepada pihak-pihak yang terkait dengan upaya dominasi terhadap pihak-pihak tertentu. John B. Thompson, sebagaimana dinukil oleh Bagus Takwin, menyebutkan lima modus umum dari cara ideologi beroperasi untuk mempertahankan suatu dominasi via penyebaran dan penularan makna. Kelima modus tersebut adalah legitimasi (legitimation), dissimulasi (dissimulation), unifikasi (univication), fragmentasi (fragmentasi), dan reifikasi (reification). Tiap modus umum ini memiliki strategistrategi khusus untuk mengkonstruksi makna-makna. Bangunan simbolik ini kemudian bertahan dan menetap sebagai pelanggeng dominasi. ${ }^{21}$

Sementara itu, Strukturalisme pada awalnya berangkat dari teori linguistik Ferdinand de Saussure yang menekankan pentingnya struktur bahasa dalam mempelajari linguistik. Dalam kajian linguistiknya, de Saussure membagi bahasa kepada dua bagian, yaitu langue yang merupakan sistem bahasa yang memiliki struktur gramatikal yang ajeg dan baku (sebuah bahasa disesuaikan dengan aturan tata-bahasa baku), dan parole sebagai ungkapan individual, tidak terstruktur dan unik (tampil dalan dialek, ujaran perorangan, dan gaya bahasa). Linguistik de Saussure menjadikan bahasa sebagai sebuah objek ilmu empiris, melalui sebuah putusan epistemologis yang memberikan prioritas pada langue sebagai sistem bahasa yang terstruktur dan mengabaikan parole sebagai ekspresi individual yang unik. ${ }^{22}$ Pemisahan antara langue dengan parole, membedakan aspek sosial dengan aspek individual sekaligus aspek esensial dengan aspek yang bersifat tambahan dan aksidental' ${ }^{23}$

Namun Robert Scholes menyatakan bahwa perangkat konsep dasar analisis struktural yang dikembangkan oleh de Saussure via magnum opusnya Cours de Linguistique Generale yang diterbitkan pertama sekali pada tahun 1915 berisi pendefinisian bahasa. Melalui karya tersebut de Saussure membagi kepada 3 level aktifitas linguistik, yakni language, langue, dan parole. Pernyataan ini diungkapkan Schole seperti berikut ini:

In the Cours Saussure begins by defining language itself. His definition is unusual in that it distinguishes three levels of linguistic activity: language, langue, and parole. Langauge is the broadest aspect, for it includes the entire human potential for spceech, both physical and mental...Langue is the language-system which each if us uses to generate discourse that is intelligible to other. Our individual utterance are what Saussure calls parole. Thus language is linguistic potential, langue is a language system, and parole is individual utterance. ${ }^{24}$

${ }^{21}$ Takwin, Akar-akar Ideologi, h. 128.

${ }^{22}$ Ibid., h. 76.

${ }^{23}$ Anthony Giddens, Problematika Utama dalam Teori Sosial: Aksi, Struktur, dan Kontradiksi dalam Analisis Sosial, terj. Daniyatno (Yogyakarta: Pustaka Pelajar, 2009), h. 4.

${ }^{24}$ Robert Scholes, Structuralism in Literature: an Introduction, cet. 7 (New Haven and London: Yale University Press, 1977), h. 14. 
Strukturalisme merupakan suatu gerakan pemikiran filsafat yang mempunyai pokok pikiran bahwa semua masyarakat dan kebudayaan mempunyai suatu struktur yang sama dan tetap. Karenanya, salah satu cara memahami pendekatan Strukturalisme adalah dengan cara memahami konsep "struktur". ${ }^{25}$ Ciri khasnya ialah pemusatan pada deskripsi keadaan aktual obyek melalui penyelidikan, penyingkapan sifat-sifat instrinsiknya yang tidak terikat oleh waktu dan penetapan hubungan antara fakta atau unsur-unsur sistem tersebut melalui pendidikan. Strukturalisme menyingkapkan dan melukiskan struktur inti dari suatu obyek secara hierarki, kaitan timbal balik antara unsur-unsur pada setiap tingkat. ${ }^{26}$ Secara sederhana, analogi yang dapat diketengahkan dalam memahami sesuatu nyaris ada kesamaan ketika memahami struktur bangunan.

Lebih lanjut, gagasan yang paling mendasar dari pendapat de Saussure ini ada empat. Pertama, diakronis dan sinkronis: penelitian suatu bidang ilmu tidak hanya dapat dilakukan secara diakronis (menurut perkembangannya) melainkan juga secara sinkronis (penelitian dilakukan terhadap unsur-unsur struktur yang sezaman). Kedua, langue dan parole: langue adalah penelitian bahasa yang mengandung kaidah-kaidah, telah menjadi milik masyarakat, dan telah menjadi konvensi. Sementara parole adalah penelitian terhadap ujaran yang dihasilkan secara individual. Ketiga, Sintagmatik dan Paradikmatik (asosiatif). Sintagmatik adalah hubungan antara unsur yang berurutan (struktur) dan paradikmatik adalah hubungan antara unsur yang hadir dan yang tidak hadir, dan dapat saling menggantikan, bersifat asosiatif (sistem). Keempat, penanda dan petanda: Saussure menampilkan tiga istilah dalam teori ini, yaitu tanda bahasa (sign), penanda (signifier) dan petanda (signified). Menurutnya setiap tanda bahasa mempunyai dua sisi yang tidak terpisahkan yaitu penanda (imaji bunyi) dan petanda (konsep). Sebagai contoh kalau mendengar kata rumah langsung tergambar dalam pikiran mengenai konsep rumah. ${ }^{27}$

Postulat dasar dari Strukturalisme Ferdinand de Saussure adalah karya wacana tidak tergantung pada maksud pembicara, pendengar atau realitas yang dibicarakan, tetapi pada struktur teks. Dalam tataran yang lebih luas, pendekatan ini bisa diaplikasikan untuk mengkaji wacana sastra, kebudayaan dan ideologi. Pada teori ideologi, postulat dasar itu menjelma menjadi pernyataan bahwa pemahaman terhadap sebuah ideologi suatu masyarakat tidak bergantung pada maksud manusia si pencetus ideologi, juga tidak pada orang-orang yang menganut ideologi tersebut, akan tetapi pada struktur yang ada pada ideologi masyarakat itu. Manusia bukanlah subjek yang menciptakan struktur, melainkan justru merupakan produk dari struktur itu. Bila implikasi analisis ini diperluas,

25"Teori Strukturalisme," dalam http://aduweh.blogspot.com/2009/07/teori-strukturalisme. html. diakses 14 Oktober 2012.

${ }^{26}$ Loren Bagus, Kamus Filsafat (Jakarta: Pustakan Gramedia, 1996), h. 1040.

${ }^{27}$ Arif Wibowo, "Strukturalisme dan Implikasinya," dalam staff.blog.ui.ac.id/arif51/2008/ 10/08/structuralis- me-dan-imp. diakses 14 Oktober 2012. 
maka dapat disimpulkan bahwa sebagian besar bentuk Strukturalisme linguistik lebih mengadopsi versi "psikologi" langue ketimbang versi "sosial"nya. ${ }^{28}$

Suatu budaya tidak bisa diproduksi dan dikembangkan dengan tepat bila tidak memiliki pengertian yang kuat tentang hakikat agensi manusia. Untuk menggunakan teori "subjek" sebagai ganti bagi asumsi bahwa subjektivitas adalah landasan pengalaman yang tidak terjembatani, Strukturalisme telah memberikan kontribusi besar, meskipun tidak ada sebuah kontribusi yang khas dari tradisi berfikir ini. Maka untuk membuat agensi manusia itu jelas, dua elemen yang cenderung tidak dimiliki dan diabaikan pemahaman Strukturalisme menurut Giddens perlu ditelaah, yakni "kesadaran praktik" dan "kontekstualitas tindakan." ${ }^{29}$ Strukturalisme cuma menghadirkan metodologi terhadap implikasi ideologi, bahkan dia merupakan sebuah metodologi yang menawarkan penyatuan atau penggabungan seluruh aspek keilmuan ke dalam sistem kepercayaan baru. Statemen ini persis seperti diungkapkan oleh Robert Scholes, yaitu, "Structuralism is at present only methodology with ideological implication, but it is a methodology which is seeking nothing less that the unification of all the sciences into a new system of belief." 30

Jika ditarik ke belakang, pendekatan Strukturalisme sebenarnya berakar pada kritik Emile Durkheim terhadap pendekatan Intelektualis yang cenderung melakukan generalisasi realitas agama dalam mendefinisikan agama dan perkembangannya pada setiap masyarakat. Karenanya, kecenderungan tradisi intelektualisme dalam meneliti adalah melihat sudut perkembangan agama dari yang animisme menuju ke monoteisme. Durkheim dalam magnum opusnya The Elementary Forms of The Religious Life, telah mengilhami banyak orang dalam melihat agama. Dalam bukunya itu ia ingin melihat agama dari bentuknya yang sangat sederhana yang diimani oleh suku Aborigin di Australia sampai ke agama yang well-structured dan well-organized seperti yang dicerminkan dalam agama monoteis. Durkheim menemukan bahwa aspek terpenting dalam pengertian agama adalah adanya distingsi antara yang sakral dan yang profan. Meskipun sebenarnya ia tidak setuju dengan pendapat yang menyatakan bahwa semua yang sakral itu selalu bersifat spiritual. Lebih lanjut, selain kritikannya terhadap pendekatan intelektualis dalam memahami agama, dia juga mengungkapkan bahwa masyarakat dikonseptualisasikan sebagai sebuah totalitas yang diikat oleh hubungan sosial. Dalam pengertian ini, menurut Durkheim masyarakat adalah "struktur dari ikatan sosial yang dikuatkan oleh konsensus moral" ${ }^{31}$ Pandangan ini yang mengilhami sekian banyak antropolog untuk menggunakan pendekatan struktual dalam memahami agama dalam masyarakat, termasuk kelembagaan yang memayungi

${ }^{28}$ Takwin, Akar-akar Ideologi, h. 77.

${ }^{29}$ Giddens, Problematika Utama, h. 366.

${ }^{30}$ Robert Scholes, Structuralism in Leterature: An Introduction (New Haven and London: Yale University Press, 1977), h. 2.

${ }^{31}$ Jamhari Ma'ruf, "Pendekatan Antropogi dalam Kajian Islam," dalam http://www.ditpertais. net/artikel/ jamhari01.asp. diakses 14 Oktober 2012. 
proses dan aktivitas penginternalisasi nilai-nilai ideologi keagamaan seperti lembaga pendidikan pesantren.

Sementara Levi-Strauss seperti dikutip Bagus, memandang dalam berbagai macam aspek sosial pun, bisa dianggap mempunyai sifat yang sama dengan bahasa; bahkan seni dan agama. Implikasi dari metodologis Strauss ini menjadi semacam postulat bagi para antropolog strukturalis; fenomena sosial apa saja yang diselidiki harus dianggap sebagai terkait pada sistem terminologi dasar (seperti kata atau fonem dalam bahasa) yang memelihara hubungan tertentu antar mereka. Sistem itu merupakan struktur yang menyatukan berbagai fenomena yang tercakup di dalamnya. Bagi Strauss, setiap fenomena tidak memiliki arti apa-apa ketika berdiri sendiri. Kumpulan fenomen (fenomena-fenomena) itu harus saling kait berkelindan dalam suatu struktur. Apa yang menerangkan fenomena itu adalah struktur yang mendasarinya, terlepas dari waktu dan orang-orang yang terlibat di dalamnya. ${ }^{32}$

Pada prinsipnya, Levi-Strauss, sebagaimana juga para ahli antropologi lainnya, secara garis besar melihat ada 3 hal yang berbeda terkait dengan hubungan antara bahasa dan kebudayaan. Hal ini penting diutarakan di sini untuk mencari formula struktur penyebaran ideologi pendidikan yang berlaku dalam dunia Pesantren. Perbedaan tersebut adalah: Pertama, bahwa bahasa yang digunakan oleh suatu masyarakat dianggap sebagai refleksi dari keseluruhan kebudayaan masyarakat yang bersangkutan. Sebagian antropolog menjadikan pandangan ini sebagai dasar untuk mempelajari kebudayaan suatu masyarakat dengan memusatkan atensinya pada bahasanya. Kedua, bahwa bahasa adalah bagian dari kebudayaan, atau bahasa merupakan salah satu unsur dari kebudayaan. Ketiga, bahwa bahasa merupakan kondisi bagi kebudayaan. Kalau pandangan pertama menempatkan bahasa sebagai suatu gejala yang setara denga kebudayaan, pandangan kedua memposisikan bahasa di bawah payung kebudayaan. Artinya, bahasa bukan merupakan sebuah fenomena yang khas, tetapi dia merupakan fenomena budaya yang tidak berbeda dengan unsur-unsur budaya lainnya seperti sistem kekerabatan, kesenian, dan sebagainya. Lain lagi dengan pandangan ketiga yang memeliki dua pengertian, yakni, (1), bahasa merupakan kondisi bagi kebudayaan dalam arti diakronis, maksudnya, bahasa mendahului kebudayaan karena memalui bahasalah manusia mengetahui budaya masyarakatnya. Contohnya, seseorang mengetahui budaya Batak, Aceh, Madura, Asmat, atau lainnya melalui bahasa mereka. (2), bahasa merupakan kondisi bagi kebudayaan karena material yang digunakannya untuk membangun bahasa pada dasarnya adalah material yang sama tipe/ jenisnya dengan material yang membentuk kebudayaan itu sendiri. ${ }^{33}$

Bagi Jacobson, Strukturalisme dibentuk berdasarkan studi tentang fenomena yang diperlakukan bukan sebagai pengorganisasian mekanis, melainkan sebagai keseluruhan

${ }^{32}$ Takwin, Akar-akar Ideologi, h. 79.

${ }^{33}$ Heddy Shri Ahimsa-Putra, Strukturalisme Levi-Strauss: Mitos dan Karya Sastra (Yogyakarta: KEPEL Press, 2006), h. 24-25. 
struktural. ${ }^{34}$ Heddy Shri Ahimsa Putra, guru besar Antropologi Universitas Gadjah Mada menyatakan bahwa dalam analisis struktural, struktur dibedakan menjadi dua macam, yakni struktur lahir/struktur luar (surface strukture) dan struktur batin/struktur dalam (deep structure). Struktur luar adalah relasi-relasi antar unsur yang dapat dibuat atau bangun berdasar atas ciri-ciri luar atau ciri-ciri empiris dari relasi-relasi tersebut, sedang struktur dalam merupakan susunan tertentu yang dibangun berdasarkan atas struktur luar yang telah berhasil dibuat, namun tidak selalu tampak pada sisi empiris dari fenomena yang kita pelajari. Struktur dalam inilah yang lebih tepat disebut sebagai model untuk memahami fenomena yang diteliti, karena peneliti akan dapat memahami berbagai fenomena budaya yang dipelajarinya. ${ }^{35}$

Sementara Giddens membahas kontekstualitas tindakan dengan menelaah ulang kehadiran dan ketidakhadiran. Kehidupan sosial manusia bisa dipahami berdasarkan relasi-relasi di antara individu-individu yang "bergerak", mengaitkan tindakan sekaligus konteks, dan membedakan satu konteks dari konteks yang lain. Konteks-konteks membentuk "latar" (setting) bagi tindakan, di mana kualitas-kualitas agen secara rutin dibentuk berdasarkan arah pengorientasian apa yang yang mereka kerjakan dan apa yang mereka katakan satu sama lain. ${ }^{36}$

Lebih lanjut Giddens menyatakan bahwa kesadaran umum terhadap latar-latar tindakan ini membentuk elemen dasar "pengetahuan mutualistik" sehingga agen-agen sanggup memahami apa yang dikatakan dan dikerjakan orang lain. Konteks tidak semestinya diidentifikasi dengan sesuatu yang membuat tindakan dan interaksi, yang terdistribusikan di dalam ruang-waktu dan direproduksi dalam "waktu yang tidak bisa dibalik" dari aktivitas sehari-hari, sangat integral bagi bentuk terstruktur kehidupan sosial dan bahasa. ${ }^{37}$

\section{Sang Kiai: Pengawal Tradisi dalam Bingkai Strukturalisme}

Urgensi konsep pendidikan yang bersifat ideologis ala pesantren dipersiapkan untuk memberikan pemikiran alternatif atau penyeimbang atas banjirnya ideologi pendidikan liberal di Indonesia. Karena itu, untuk meminimalisir sisi negatif ideologi perlu dibatasi pada pengertian ideologi netral dan ideologi terbuka. Ideologi pertama adalah sistem berpikir, nilai-nilai dan sikap, sebuah gerakan kelompok sosial atau kebudayaan. Dalam pengertian ini, baik buruknya esensi ideologi sangat tergantung pada substansi/isinya. Sedangkan yang kedua adalah ideologi yang hanya menetapkan nilai-nilai dasar, sedangkan terjemahan ke dalam bentuk praktik disesuaikan dengan prinsip-prinsip moral dan perkembangan cita-cita masyarakat. Operasionalisasinya ditentukan oleh kesepakatan

\footnotetext{
${ }^{34} \mathrm{R}$. Jacobson, Word and Language (Hague: Mouton, 1971). h. 711.

${ }^{35}$ Putra, Strukturalisme Levi-Strauss, h. 61.

${ }^{36}$ Giddens, Problematika Utama, h. 367.

${ }^{37}$ Ibid.
} 
yang demokratis. ${ }^{38}$ Sistem pendidikan pesantren sangat menekankan aspek pengetahuan dan kebajikan. Untuk itu, para santri ditugaskan tidak hanya menguasai ilmu pengetahuan, tetapi intelektual dan emosional mereka dilatih juga dengan nilai-nilai agama, sehingga eksistensi ilmu-ilmu yang berorientasi keduniaan adalah untuk memperkuat keyakinan para santri terhadap kebesaran dan kekuatan Sang pencipta. ${ }^{39}$

Salah satu strategi penyebaran suatu ideologi sebagaimana diutarakan oleh Terry Eagleton di atas adalah naturalisasi, yakni usaha untuk menampilkan sebuah ideologi/ kepercayaan sebagai suatu yang tampak alamiah. Lebih luas naturalisasi masuk dalam ranah subordinat modus umum dari reifikasi tentang cara ideologi beroperasi. Menurut Thompson, seperti dikutip Takwin, sebenarnya istilah reifikasi ini merujuk pada konsep ideologi dari Lucacs, yakni hubungan dominasi dapat dibentuk dan dipertahankan dengan cara merepresentasikan suatu kondisi yang bersifat sementara atau historis dengan gambaran seolah-olah bersifat permanen dan alamiah. ${ }^{40}$

Penyebaran ideologi pendidikan pesantren di Indonesia juga dilakukan secara alamiah melalui perjalanan sejarah yang cukup panjang, mulai dari model yang ditampilkan oleh Muhammad SAW. sebagai founding father-nya pendidikan Islam sampai kepada pencarian pencerahan intelektual-spritual oleh para ulama sebagai pewaris risalah kenabian. Sejarah mencatat betapa pengikut atau murid Nabi Muhammad SAW. telah berhasil menerangkan dan meneruskan ajaran tentang semangat menuntut ilmu. Motivasi religius ini juga ditemukan dalam tradisi rihhlah (pengembaraan) yang disebut dengan al-rihlah fî thalab al-ilm (pengembaraan dalam rangka menuntut ilmu) atau dalam istilah modern disebut the spirit of inquiry merupakan bukti sedemikian besarnya rasa keingintahuan di kalangan para ulama.

Aktivitas rihlah bukan sekedar merupakan tradisi akademis belaka, namun juga merupakan syarat utama untuk menuntut ilmu. George Makdisi mengutip pernyataan Imam al-Haramain al-Juwainî (w. 1085 M.), seorang Sunni ahli Kalam kenamaan, memberikan kriteria yang melambangkan sebuah tradisi dinamis dalam proses mencari ilmu pada masa pra-modern. Kebutuhan-kebutuhan yang diperlukan dalam tradisi itu adalah kecerdasan, semangat hidup dalam kemiskinan, merantau ke negeri asing, inspirasi seorang guru, dan belajar sepanjang hayat (long life education) ${ }^{41}$ Bahkan menariknya lagi ilustrasi statemen Nabi Muhammad SAW. yang menyatakan bahwa jauhnya letak suatu negara bukanlah masalah untuk kepentingan mencari kemuliaan nilai ilmu

${ }^{38}$ Achmadi, Ideologi Pendidikan Islam, h. 20.

${ }^{39}$ Ali Ashraf dan Sajjad Husein, Pergulatan Ideologis Pendidikan Islam: Refleksi Pendidikan Islam dalam Menemukan Identitas di Era Global, terj. Mukani (Malang: Madani Media, 2011), h. 17.

${ }^{40}$ Takwin, Akar-akar Ideologi, h. 134.

${ }^{41}$ George Makdisi, The Rise of Colleges: Institutions of Learning and in Islam the West (Edinburgh: Edinburgh University Press, 1981), h. 1. 
pengetahuan (uthlub al-'ilma wa lau bi al-shîn). Hal itu diwariskan secara berkelanjutan dari generasi ke generasi demi langgengnya spirit thalab al-'ilm.

Proses internalisasi nilai-nilai ideologi yang menyejarah tersebut ke dalam relung jiwa para santri tidak dilakukan secara anarkis dan pemaksaan, namun sebaliknya materilah yang membentuk kesadaran subjek (santri) untuk mengadopsi ideologi itu secara suka rela, di samping tampilan kiai sebagai model figur pendidikan dalam dunia pendidikan di pesantren. Salah satu contoh model figur dalam sejarah pesantren abad XV - XVI di pulau Jawa, seperti diketengahkan oleh Abdurrahman Mas'ud adalah Maulana Malik Ibrahim (w. 1419 M.) yang bagi santri Jawa merupakan spiritual father of Walisongo, dipandang sebagai gurunya guru tradisi pesantren. Di luar Jawa, dia juga sangat terkenal dan menjadi prototipe lembaga pendidikan Islam semisal Nahdhatul Wathan di Lombok yang didirikan tahun 1934 di Pancor Lombok Timur NTB dan dewasa ini santrinya tidak kurang dari sepuluh ribu orang dengan cabangnya di Jakarta. Model pendidikan tersebut ternyata diinspirasi dari ajaran dakwah Islam Maulana Malik Ibrahim. ${ }^{42}$ Hubungan kiai-santri tersebut merupakan kelanjutan konsep hubungan "guru-cantrik" yang ada sebelum Islam datang di tanah Dwipa, atau sekurang-kurangnya dipengaruhi konsep stratifikasi masyarakat Jawa. Santri akan selalu memandang kiai atau gurunya dalam pengajian sebagai orang yang mutlak harus dihormati, malahan dianggap memiliki kekuatan ghaib yang dapat membawa keberuntungan (berkah) atau celaka (mudharat). ${ }^{43}$

Menghindari punahnya sebuah tradisi pesantren, sarana utama yang dibangun oleh kiai adalah solidaritas dan kerjasama. Cara praktis yang ditempuh untuk membangun kedua sarana tersebut adalah (1) mengembangkan suatu tradisi bahwa keluarga yang terdekat menjadi calon kuat pengganti posisi leadership pesantren, (2) mengembangkan suatu jaringan aliansi perkawinan endogamous antar keluarga kiai, dan (3) mengambangkan tradisi transmisi pengetahuan dan rantai transmisi intelektual antara sesama kiai dan keluarganya. ${ }^{44}$ Kemampuan dalam melestarikan dan mempertahankan eksistensi tradisi pesantren di tengah-tengah gelombang modernisasi dan globalisasi saat ini menuai ragam pandangan. Setidaknya, ada dua pandangan yaitu pandangan pesimis yang melihat pesantren merupakan lembaga pendidikan tradisional yang eksklusif sulit berkembang di tengah proses modernisasi. Hal ini karena pola pendidikan yang dibangun selama ini terlalu lamban untuk mencetak sosok alumni yang diharapkan masyarakat modern. Sedangkan kalangan yang optimis justeru memandang pesantren sebagai lembaga pendidikan dan pemberdayaan masyarakat sampai kapan pun akan tetap eksis. Karena pesantren merupakan lembaga pendidikan Islam yang memiliki karakteristik tradisional, indigenous

${ }^{42}$ Mas'ud, Intelektual Pesantren, h. 49.

${ }^{43}$ Nurcholish Madjid, Bilik-bilik Pesantren: Sebuah Potret Perjalanan (Jakarta: Dian Rakyat, t.t.), h. 26.

${ }^{44}$ Zamakhsyari Dhofier, Tradisi Pesantren: Studi Pandangan Hidup Kiyai dan Visinya Mengenai Masa Depan Indonesia, cet. 8 (Jakarta: LP3ES, 2011), h. 101. 
dan unik yang kelahirannya memang untuk memenuhi tuntutan dan kebutuhan masyarakat terutama masyarakat pedesaan. Di samping itu, pesantren juga merupakan salah satu lembaga sosial keagamaan independen alternatif untuk sebuah perubahan. ${ }^{45}$

Struktur pendidikan pesantren sebagaimana diungkapkan sebelumnya merupakan perangkat yang menyokong ketahanan eksistensi durasi masa sebuah lembaga pesantren itu bertahan. Analisis ideologi pendidikan pesantren dalam paradigma Strukturalisme menunjukkan bahwa struktur pertama dari elemen dasar pendidikan pesantren, yaitu kiai sangat menentukan langgeng tidaknya kiprah ideologi tersebut. Kepiawaian seorang kiai dalam mengelola sistem yang berjalan di dunia pesantren tidak saja pada tataran proses transformasi ilmu pengetahuan saja, tetapi juga dalam menjaga ciri-ciri tradisional pra-modern seperti hubungan intim guru-murid yang didasarkan lebih pada suatu sistem kepercayaan daripada hubungan patron-client yang berkembang luas di masyarakat. Para santri menerima kepemimpinan kiai karena percaya kepada konsep "keberkahan" yang beranjak atas doktrin keistimewaan status seorang 'alîm dan wali. Nawawi alBantani misalnya, menerima ciuman tangan dari hampir seluruh masyarakat Jawa yang tinggal di Makkah sebagai sebuah ekspresi penghormatan ilmu dan moral secara simbolik, bukan secara pribadi. Nawawi tidak pernah menolak undangan atau ajakan apa pun yang berhubungan dengan pembahasan fikih. Ciuman tangan simbolik ini tentu sangat bias jika dipandang sebagai gejala feodalisme di mata sarjana modern. Namun komunitas pesantren menganggap ciuman terhadap tangan seorang 'alîm (kiai) akan mendatangkan berkah, dan sebagai bagian dari implementasi sunnah. Bahkan menurut pengikut Syâfiî̀ (mazhab fikih mayoritas komunitas pesantren), mencium tangan tidak hanya kepada seorang 'alîm, tetapi juga kepada zahid (orang yang zuhud), syarif (orang yang dihormati karena tingkat pemahaman keagamaannya), para sesepuh, bayi dan teman yang datang dari tempat atau negeri jauh.

Keberadaan kiai sebagai media kominukasi di tengah-tengah komunitas santri sangat menentukan bagi penanaman ideologi yang memang kadang sudah berlaku. Di tambah lagi kiai-tidak hanya menyediakan tempat dan kesempatan bagi studi teks-teks keagamaan (kitab kuning), tetapi yang lebih penting, mereka tampil sebagai pusat komunikasi bagi segala macam lapisan masyarakat pedesaan dari yang miskin hingga yang kuat (kaya). Di sisi lain, seorang kiai juga merupakan model bagi pengikutnya (santri dan masyarakat), di mana identitas kekiaian itu sendiri disematkan oleh masyarakat karena kepahaman dan kedalaman ilmu-ilmu keislamannya serta kewibawaan kepribadiannya. Jadi gelar kiai bukan hasil produksi sebuah lembaga pendidikan formal, semisal sekolah tinggi atau universitas. Ronald Alan Lukens-Bull mengatakan bahwa istilah "kiai" dalam

${ }^{45}$ In'am Sulaiman, Masa Depan Pesantren: Eksistensi Pesantren di Tengah Gelombang Modernisasi (Malang: Madani, 2010), h. 12-13. 
bahasa Jawa merujuk kepada banyak hal. Semua hal ini menunjukkan kepada "sesuatu" atau "seseorang" yang memiliki kualitas di atas rata-rata. ${ }^{46}$

Dilihat dari perspektif seorang perencana, think-tank metropolis, kiai begitu lamban dan bersahaja dalam merespons perubahan, namun tidak dapat disangkal bahwa pengalaman panjang kiai dalam kaitannya dengan masyarakat pedesaan dan isu-isu lokal telah menjadikan mereka berhati-hati dalam mendukung hal-hal yang baru.

Ketika pendidikan modern menjadi penting bagi kehidupan masyarakat modern, dan tidak hanya para pelajar yang potensial memiliki kesempatan untuk mengikuti studi lanjutan/tinggi, maka model pendidikan pesantren menjadi relevan untuk masa sekarang. Kemudahan masuk yang diberikan oleh kiai dan pesantrennya membuat keterlibatan dari semua lapisan masyarakat menjadi mungkin, termasuk pendaftaran di dalam fasilitasfasilitas pendidikannya. Sekarang, adalah menjadi tanggungjawab negara dan masyarakat untuk menyediakan atmosfer pendidikan yang lebih kondusif, dan pesantren dapat memberikan akomudasi yang lebih besar bagi para penuntut ilmu pengetahuan tanpa hambatan biaya dan birokrasi. Sesungguhnya, pesantren dapat memainkan peran yang lebih sentral dalam mewujudkan wajib belajar pendidikian tinggi dewasa ini.

Setelah memaparkan potensi dan kekuatan kiai dan dunia pesantrennya, tetaplah penting untuk menempatkan persoalan ini dalam konteks perubahan yang sangat cepat dan globalisasi dunia di mana manusia hidup sekarang, termasuk kiai ada di dalamnya dan menghadapinya. Kiai senantiasa relevan dan penting bukan karena kebajikan dari simbol-simbol itu atau bahkan institusi-institusi fisik yang telah mereka buat lewat kemampuannya dalam menerjemahkan nilai-nilai dan norma-norma keagamaan secara historis dan sosiologis, bukan untuk memelihara spritualitas atau intelektualitas, tetapi menjadi panduan yang sarat makna dan mudah.

Bagaimanapun, kaum santri sangat memahami bahwa penghormatan fisik tersebut tidak boleh dicampur adukkan dengan keimanan dalam Islam yang menyaratkan keesaan Tuhan yang mutlak untuk disembah. Sejak Islam menjadi agama yang mayoritas dianut di bumi Nusantara, kiai menikmati status sosial yang tinggi. Para kiai sudah terbiasa terlibat langsung secara fisik dalam tatanan dan berbagai aktivitas sosial. Menariknya lagi adalah peran para kiai (pulau Jawa sebagai sampel kasus) dalam menyebar luaskan ilmu pengetahuan, mengembangkan kurikulum, dan menanggapi tantangan dari luar, khsususnya dari pemerintahan Belanda (era Kolonial). Aspek kepemimpinan kiai ini sangat penting karena akan menunjukkan bagaimana para kiai menjaga hubungan harmonis baik dengan komunitas umum maupun dengan para kiai lainnya. Dalam hal fungsi pendidikan, satu kenyataan penting muncul, yakni pemeliharaan tradisi Islam di mana oleh para ulama menjadi penjaga utama ilmu keagamaan par-excellent. Peran ini tidak bisa diwakilkan

${ }^{46}$ Ronald Alan Lukens-Bull, Jihad Ala Pesantren di Mata Antropolog Amerika, terj. Abdurrahman Mas'ud, et al. (Yogyakarta: Gama Media, 2004), h. 89. 
kepada kelompok lain dalam komunitas Islam karena sebuah keyakinan bahwa "para ulama adalah pewaris Nabi". Para kiai selanjutnya menjadi satu-satunya interpreter yang sah atas dua sumber utama Islam yaitu al-Qur'an dan Sunnah Nabi. Peran pengesahan ajaran agama ini merupakan basis di mana pengetahuan kiai ditransfer dari generasi ke generasi di dalam pesantren.

Pesantren-pesantren yang awalnya berlokasi di daerah terpencil dan pedesaan bisa juga dipandang sebagai kerajaan kecil di bawah perintah mutlak sang kiai. Inilah otoritas Islam yang ada dalam lokalitas masyarakat Indonesia dalam arti aktual dan faktual. Kasus masyarakat Jawa sangat tergantung kepada bimbingan para kiai bahkan dalam hal mengambil keputusan atas berbagai persoalan, seperti harta benda, pernikahan, warisan dan yang sejenisnya. Situasi ini, dipadu dengan sikap para kiai yang lebih mengambil jarak dengan pemerintah (pada era kolonial; dengan pemerintah Kolonial), memberikan kepada mereka otoritas moral dan religius dan menampakkan ciri mereka sebagai kelas berpendidikan tersendiri.

Mayoritas para penulis Islam Indonesia yang ada bukanlah para sarjana yang memiliki latar belakang studi islam (Islamic Studies) yang misleading dalam menilai peran dan fungsi ajaran-ajaran Islam dalam kehidupan masyarakat pesantren, khususnya masyarakat Jawa. Kiai dengan teologi Asy'ari-nya yang dominan pada umumnya dipandang sebagai "figur primitif yang pasif" dengan pakaian tradisional, sarung, yang lebih banyak berpikir tentang keakhiratan dan mengambil sikap diam terhadap berbagai penindasan kaum elit. Komunitas kaum kiai seringkali salah dinilai, dan dipandang lebih sebagai orangorang Indonesia yang pendiam daripada Muslim yang revolusioner, yang lebih menekankan pikiran daripada tindakan. Implikasinya bahwa seorang Muslim Jawa (misalnya) oleh para sarjana tersebut lebih dipandang sebagai seorang Jawa daripada seorang Muslim yang revolusioner.

Pernyataan tersebut dalam beberapa hasil penelitian ditolak dan dikoreksi oleh beberapa sarjana terkemuka. Snouck Hurgronje, misalnya menyatakan bahwa dalam dekade pertama abad XX, ia mengingatkan para koleganya di Netherlands East Indies civil Service bahwa Islam Indonesia, yang tampaknya begitu statis, begitu terbenam dalam kelambanan Abad Pertengahan, mengalami perubahan yang fundamental, namun perubahan-perubahan tersebut terjadi sedemikian bertahap, begitu halus, terkonsentrasi di tempat-tempat terpencil dan tidak pernah terlintas dalam benak non-Muslim, sehingga meski perubahanperubahan itu terjadi di depan mata tetapi terabaikan oleh para sarjana yang tidak cermat dalam mengkaji masalah ini. ${ }^{47}$

Struktur selanjutnya yang mengidentifikasi terjadinya proses pengakaran ideologi dalam jasad pendidikan pesantren adalah santri dengan jaringan intelektual yang

${ }^{47}$ Snouck Hungronje, Mecca in the Later Part of the Nineteenth Century (Leiden: E.J. Brill, 1931), h. 280. 
dibangun sesamanya. Fakta sejarah mengungkapkan bahwa watak pesantren yang memberikan konstribusi terhadap kemandirian dan ketahanan akan dominasinya dalam melawan serangan-serangan dari luar telah membuka jalan bagi para santrinya untuk membuat jaringan kepesantrenan. Identitas dan solidaritas sesama santri terus dipupuk melalui paket jejaring yang sangat solid. Nilai-nilai ideologi pendidikan pesantren yang selama ini mereka peroleh di lembaganya terus dipelihara dengan penguatan-penguatan yang nyata melalui pembentukan kelompok-kelompok pengajian. Intensitas pertemuan mereka dalam diskusi agama yang diadakan secara bergiliran dari satu pondok pesantren ke pondok lainya mempertegas kekentalan hubungan sturktural antara para santri tersebut. Aktivitas intelektual dan akademik merupakan ciri-ciri yang paling menonjol dari jaringan yang dibangun para santri. Para santri Jawa yang berkelana baik di dalam pulau Jawa maupun di luar Jawa (misalnya Timur Tengah), hubungan mereka dengan para gurunya tidak pernah dapat dipisahkan oleh waktu dan tempat, bahkan hubungan tersebut merupakan ikatan sepanjang hidup.

Lain lagi dengan keanggotaan jaringan tarekat yang mungkin merupakan afiliasi paling solid dan krusial berdasarkan fakta bahwa jaringan itu diperkokoh dengan kesetiaan para pengikutnya dan perjuangan untuk meningkatkan kualitas kesalehan mereka di bawah seorang guru sufi. Sufisme dan tarekat tidak dapat dipisahkan dan berakar dalam kehidupan masyarakat Indonesia sehari-hari, terutama di Jawa, karena ia memiliki model yang kuat seperti Walisongo.

Bangunan bentuk jaringan lainnya untuk mempererat tali ikatan antara gurumurid adalah dengan mengadopsi santri sebagai anak menantu. Pernikahan dengan cara sudah biasa terjadi dalam tradisi pesantren; ditujukan kepada santri yang diharapkan dapat meningkatkan kualitas kharisma pesantren di masa depan. Di sisi lain, Zamakhsyari Dhofier mengungkapkan bahwa terdapat inter-pernikahan lain antara keluarga pesantren. Pernikahan ini mengandung arti bahwa ikatan di antara dua pesantren menjadi semakin kuat, dikarekan hubungan tersebut tidak hanya dibangun atas dasar unsur keagamaan tetapi juga atas dasar persaudaraan. Selain itu, persaudaraan dipandang sebagai sumber kemajuan, kesejahteraan dan kekuatan dalam kultur pesantren. ${ }^{48}$

Di tengah signifikansi posisi sang kiai, kehidupan religius santri berada pada sebuah atmosfer kondusif untuk menjadi pendukung dan legitimasi atas apa yang dinamakan "penguasa yang saleh". Ideologi yang disemai para kiai dalam lubuk hati para santri begitu terpatri hingga menyentuh sendi-sendi kehidupan dan terus dipupuk melalui jargon-jargon ajaran agama. Materi kitab kuning yang merupakan unsur lainnya dari struktur pesantren menjadi esensi penting dalam proses penyampaian pengalaman ilmu pengetahuan di kalangan pesantren. Aktifitas belajar biasanya dilakukan di tempat-tempat tertentu, bahkan

${ }^{48}$ Zamakhsysari Dhofier, Tradisi Pesantren: Memadu Modernitas Untuk Kemajuan Bangsa (Yogyakarta: Pesantren Nawesea Press, 2009), h. 54-58. 
terkadang disediakan tempat yang biasa untuk meletakkan kitab-kitab guru/kiai. Model belajar seperti ini dilakukan dengan cara, murid menyodorkan kitab yang hendak diulang, dan berhadapan langsung secara giliran secara tatap muka kepada guru. ${ }^{49}$

Kegiatan selanjutnya, guru membaca kitab yang disodorkan oleh si murid dan menerjemahkannya baik dengan bahasa Indonesia atau dengan bahasa daerah. Dalam situasi ini, si murid mendengarkan dengan tekun bacaan guru seraya melakukan pencatatan bunyi ucapan teks kitab dengan memberikan syakal terhadap kata-kata Arab yang ada dalam kitab. Selain memberi syakal, si murid juga mencatat terjemahan makna dari kata-kata Arab yang dianggap sukar di pinggir margin kitab atau di bawah huruf Arab. Setelah selesai dibacakan oleh guru, selanjutnya si murid mengulang kembali bacaan tersebut dan kali ini guru yang menyimak bacaan murid sambil mengoreksi bacaan-bacaan yang salah.

Tradisi belajar yang demikian sebenarnya telah menunjukkan tradisi kritis terhadap kajian kitab yang dilakukan antara guru dan murid. Catatan-catatan yang dilakukan oleh murid baik dengan memberikan syakal tentunya mempunyai alasan mengapa berbaris dhammah, fathah $\underline{h}$ atau kasrah, dan ini tentu saja diberi catatan dipinggir dengan tulisan huruf latin. Begitu pun dengan terjemahannya. Nilai-nilai yang ada dalam kitab kuning dipahami, direnungi kemudian diamalkan oleh para santri sebagai tuntunan dalam pergaulan kehidupan beragama dan bermasyarakat.

\section{Penutup}

Pesantren sebagai lembaga pendidikan menjadi sangat potensial dan memiliki arti yang sangat istimewa bukan hanya bagi usaha transformasi ilmu pengetahuan tetapi juga bagi objektivikasi sebuah ideologi pada diri santri sebagai elemen sentral selain kiai dalam sebuah ranah pendidikan pesantren. Keberadaannya yang sudah menyejarah terlihat dalam perjuangannya melawan penjajahan Kolonial (Portugis, Belanda dan Jepang) dengan menggunakan justifikasi religius dan term-term simbolik seperti perang suci (Aceh: prang sabie) untuk mengusir orang kafir. Keunikannya terletak dalam paduan budaya lokal dengan substansinya sebagai satu keseluruhan pandangan hidup Islam. Perlu dicatat bahwa semakin keras penindasan yang dilakukan oleh kaum kolonial, maka akan semakin menghebat pula perlawanan yang dilancarkan oleh komunitas pesantren. Dari ilustrasi ini, ideologi pendidikan pesantren yang tertanam dalam jiwa para pengikutnya sangat kuat dan mengakar sekali.

Strategi penyebaran ideologi tersebut dilakukan melalui kepiawaian kiai dan kedalaman ilmu yang dimilikinya, menjadikan dia sebagai sentral figur bagi komunitasnya dalam mengarungi jejak kehidupan ini. Jaringan yang dibangun antar para alumni dan masyarakat menjadikan nilai-nilai ideologi semakin subur tertanam dan sangat merakyat

${ }^{49}$ Muslim Thahiri, et al., Wacana Pemikiran Santri Dayah Aceh (Banda Aceh: BRR NADNIAS, PKPM Aceh dan Wacana Press, 2006), h. 159. 
sehingga dalam praktik pun tidak mengalami kesulitan. Hal ini karena kesadaran dan keserasian dengan kultur lingkungan pesantren yang bersinergi dengan kehidupan masyarakat di mana pesantren itu berada. Peran kiai sebagai pemegang tampuk otoritas di pesantren sangat dominan, sehingga ideologi-ideologi yang ditransfer dan diinternalisasi menjadi sangat lekat dan menempel erat dalam segenap serat kehidupan civitas akademika pesantren. Kemapanan pemahaman kiai sebagai agen dalam menyampaikan pesan-pesan ideologi terhadap karakter dan perilaku komunitasnya memudahkannya melakukan objektivikasi materi kepesantrenan.

\section{Pustaka Acuan}

Abdullah, Abdurrahman Saleh. Teori-teori Pendidikan Berdasarkan al-Qur'an, terj. M. Arifin. Jakarta: Rineka Cipta, 1990.

Achmadi, Ideologi. Pendidikan Islam: Paradigma Humanisme Teosentris. Yogyakarta: Pustaka Pelajar, 2005.

Ashraf, Ali, dan Sajjad Husein. Pergulatan Ideologis Pendidikan Islam: Refleksi Pendidikan Islam dalam Menemukan Identitas di Era Global, terj. Mukani. Malang: Madani Media, 2011

Bagus, Loren. Kamus Filsafat. Jakarta: Pustakan Gramedia, 1996.

Bull, Ronald Alan Lukens. Jihad Ala Pesantren di Mata Antropolog Amerika, terj. Abdurrahman Mas'ud, et al. Yogyakarta: Gama Media, 2004.

Dhofier, Zamasysari. Tradisi Pesantren: Memadu Modernitas untuk Kemajuan Bangsa. Yogyakarta: Pesantren Nawesea Press, 2009.

Dhofier, Zamasysari. Tradisi Pesantren: Studi Pandangan Hidup Kiai dan Visinya Mengenai Masa Depan Indonesia, cet. 8. Jakarta: LP3ES, 2011.

Daud, Al Husaini M. "Ideologi dan Ketidakpuasan.” Makalah, tidak diterbitkan.

Eagleton, Terry. Ideology: An Introduction. London: Thetford Press, 1991.

El Zastrow, Ngatawi. Dialog Pesantren-Barat: Sebuah Transformasi Dunia Pesantren, dalam Mihrab, Edisi I, tahun IV, 2006.

Fakih, Mansour. "Pengantar," dalam William O'neil. Ideologi-ideologi Pendidikan, cet. 2. Yogyakarta: Pustaka Pelajar, 2008

Giddens, Anthony. Problematika Utama dalam Teori Sosial: Aksi, Struktur, dan Kontradiksi dalam Analisis Sosial, terj. Dariyatno. Yogyakarta: Pustaka Pelajar, 2009

Haedari, Amin. Panorama Pesantren dalam Cakrawala Modern. Jakarta: Diva Pustaka Jakarta, 2005.

Hungronje, Snouck. Mecca in the Later Part of the Nineteenth Century. Leiden: E.J. Brill, 1931.

Jacobson, R. Word and Language. The Hague: Mouton, 1971. 
Ma'ruf, Jamhari. "Pendekatan Antropogi dalam Kajian Islam.” dalam www.ditpertais.net/ artikel/ jamhari01.asp.

Madjid, Nurcholish. Bilik-bilik Pesantren: Sebuah Potret Perjalanan. Jakarta: Dian Rakyat, t.t.

Makdisi, George. The Rise of Colleges: Institutions of Learning in Islam in the West. Edinburgh: Edinburgh University Press, 1981.

Mas'ud, Abdurrahman, Intelektual Pesantren: Perhelatan Agama dan Tradisi, Yogjakarta, LKis, 2004.

Maunah, Binti. Tradisi Intelektual Santri dalam Tantangan dan Hambatan Pendidikan Pesantren di Masa Depan. Yogjakarta: Teras, 2009.

O'neil, William. Ideologi-ideologi Pendidikan, cet. 2. Yogjakarta: Pustaka Pelajar, 2008.

Putra, Heddy Shri Ahimsa. Strukturalisme Levi-Strauss, Mitos dan Karya Sastra. Yogyakarta: KEPEL Press, 2006.

Steenbrink, Karel. A. Pesantren, Madrasah dan Sekolah. Jakarta: LP3ES, 1986.

Scholes, Robert. Structuralism in Leterature: An Introduction, cet. 7. New Haven and London: Yale University Press, 1977.

Sulaiman, In'am. Masa Depan Pesantren: Eksistensi Pesantren di Tengah Gelombang Modernisasi. Malang: Madani, 2010.

Sulaiman, M. Isa. Sejarah Aceh: Sebuah Gugatan Terhadap Tradisi. Jakarta: Pustaka Sinar Harapan, 1997.

Takwin, Bagus. Akar-akar Ideologi: Pengantar Kajian Konsep Ideologi dari Plato hingga Bourdieu, cet. 2. Yogjakarta: Jalasutra, 2009.

“Teori Strukturalisme.” Dalam http:/www.aduweh.blogspot.com/2009/07/teoriStrukturalisme.html.

Thahiri, Muslim, et al. Wacana Pemikiran Santri Dayah Aceh. Banda Aceh, BRR NAD-NIAS, PKPM Aceh dan Wacana Press, 2006.

Thompson, John B. Ideology and Modern Culture. Cambridge: Polity Press, 1990.

Wahid, Abdurrahman. "Pesantren sebagai Subkultur," dalam M. Dawam Raharjo (ed.), Pesantren dan Pembaharuan, cet. 4. Jakarta: Lembaga Penelitian, Pendidikan dan Penerangan Ekonomi dan Sosial-LP3ES, 1988.

Wibowo, Arif. "Strukturalisme dan Implikasinya." dalam http://www.staff.blog.ui.ac.id/ arif51/2008/10/08/ structuralisme-dan-imp. 